\title{
Understanding Stories of Professional Formation during Early Childhood Education and Care (ECEC) Practice Placements
}

Mark Taylor

Goldsmiths, University of London

Department of Social, Therapeutic and Community Studies, Goldsmiths, University of London, New Cross, London SE14 6NW, UK

Email: m.taylor@gold.ac.uk 


\section{Understanding Stories of Professional Formation during Early Childhood Education and Care (ECEC) Practice Placements}

Narrative inquiry as a methodological approach enables us to examine how people represent their experiences and selves through storytelling (Chase, 2005). To understand these constructions, other kinds of knowledge are required. Theories of social life, for example, help to interpret areas which narrative inquiry is good at revealing about human experiences such as the animation of temporality, sociality and place (Clandinin et al., 2015). Drawing on interviews with practice educators and final-year Undergraduate Early Childhood Education and Care (ECEC) students in North-West Ireland, this paper considers how narrative inquiry and education theories work together to illuminate key learning experiences of ECEC undergraduate students during 12-week practice placements. In this paper I attempt to show how two education theories - 'Threshold Concepts' and 'Communities of Practice' - shed light on the nature of these key learning experiences. The paper suggests that narrative inquiry offers an emancipatory research approach by uncovering human and reflective elements of learning journeys made by ECEC students during their practice placements.

Keywords: early childhood education and care, professional development, narrative inquiry.

\section{Introduction}

Qualitative research asks researchers to align substantive, theoretical and methodological aims (Wallace \& Wray, 2011) in order to interpret, understand and present the meanings of social experiences. Keeping this alignment in mind can therefore unlock stories of how practice placements are experienced by students training to become teachers. Here the use of the term 'stories' is deliberate. Researchers have been eliciting stories about educational experiences for over 30 years (e.g. Clandinin \& Connelly, 1986) as human experiences have come to be understood ontologically as a 
phenomenon that can be investigated through narrative inquiry (Clandinin et al., 2015). This paper considers how meanings became attached to stories told by respondents where the substantive aim of a research project (see Taylor, 2015) was to understand the nature of key learning experiences for Early Childhood Education and Care (ECEC) students during their practice placements. The history of narrative inquiry within education research reveals its disruptive capacity (Huber et al., 2013). The intention of this paper is to demonstrate the potential of narrative inquiry and education theory to work together to disrupt our understanding of education. The first section of the paper briefly reviews the application of narrative inquiry in education research, with some emphasis placed on literature concerned with the experiences of 'becoming' a teacher (Clandinin \& Connelly, 1986). Thereafter the paper justifies using narrative inquiry to examine the learning experiences of ECEC students during practice placements. The three 'commonplaces' (Clandinin \& Huber, 2010) of narrative inquiry are then considered as a way to illuminate stories about placement learning experiences of ECEC students. However, narrative inquiry by itself is unable to explain these experiences. Education theories were used to understand these 'commonplaces'. This paper makes use of two education theories: 'Threshold Concepts' (Meyer and Land, 2003) and 'Communities of Practice' (Lave \& Wenger, 1991). Drawing on these education theories, findings are then presented to reveal the richness of narrative inquiry, pointing to the presence of temporality, sociality and place in respondents' accounts of how they tell stories about key learning experiences for students during ECEC practice placements. The paper then discusses the findings, highlighting the opportunities provided by narrative inquiry to explore human and reflective elements of learning for ECEC students on placement. The paper concludes by acknowledging that while there are limits to the generalizability of findings in narrative inquiry, the 
methodological approach offers reflective, creative and emancipatory possibilities in education research.

\section{Narrative Inquiry and Education Research}

Since its emergence 30 years ago when Clandinin \& Connelly (1990) first coined the term 'narrative inquiry' in a published article, Kim (2015) notes that narrative inquiry has become an influential research methodology in education research. Clandinin \& Rosiek (2007, p.68) point to the 'borderlands within the community of narrative inquirers', highlighting different hubs of attraction for education researchers. Huber et al. (2013) review the use of narrative inquiry in education research and signal its emancipatory capability. Arguably this is the case because narrative inquiry is a methodological approach sympathetic to ontological and epistemological stances that foreground human experience and interpretation of the world (Clandinin et al., 2015). Similarly, Kim (2015) suggests that researchers using narrative inquiry challenge positivist claims to knowledge by recognising the lived experiences of teachers and students. Huber et al. (2013) indicate that narrative inquiry embraced a humanistic turn in the 1990s, expanding what can be understood as teacher knowledge and opening up heterogeneous constructions of childhood. In addition, Huber et al. (2013) reveal that narrative inquiry came to be seen as a methodological approach to advance social justice in education. For example, stories communicate people's experiences of structural barriers; stories can also illustrate the relationship between education and intersectional elements within people's lives (e.g. Delpit (1995) cited in Huber et al. (2013)). Narrative inquiry also unmasks the discursive positioning and repertoire at the disposal of respondent storytellers. If stories are understood to be told within the parameters of a historical, cultural and political context, then stories can also reveal the presence of dominant and disruptive discourses in relation to educational experiences 
and practices (e.g. Polakow (1994) cited in Huber et al. (2013)).

In terms of narrative inquiries into the professional development of teachers, Clandinin \& Connelly (1986) discuss the experiences of novice teachers. They highlight the benefits of narrative inquiry as a process that reframes our understanding of what counts as teacher knowledge. Narrative inquiry considers teacher knowledge as going beyond technical know-how; it furnishes novice teachers with 'opportunities for reflection upon their practice particularly at moments of contradiction and discontinuity' (Clandinin \& Connelly, 1986, p.386). In coming to understand these narratives of teaching practice, Connelly and Clandinin (1988) highlight the effect of the teacher's own personal life experience, denoted as 'personal practical knowledge', on what happens in the classroom. In order to make sense of how personal and technical knowledge in education interact, the importance element of reflection is recognised. Indeed, Kim (2015) suggests that narrative inquiry's popularity as a research methodology in education relates to its capacity to explore the process of reflective practice.

\section{Narrative Inquiry and Researching the Experiences of ECEC Students during Practice Placements}

This section examines how a narrative approach to researching the learning experiences of ECEC students during practice placements needs to be justified. The section then considers how the three 'commonplaces' (Connelly \& Clandinin, 2006, p.479) of narrative inquiry can be considered in relation to stories told of placement learning experiences. Clandinin \& Huber (2010) suggest that a narrative approach for undertaking research needs to be first justified. For them there are practical and social justifications for undertaking a narrative inquiry. There is a practical need to understand the significance of practice placements for ECEC students, as there has been a significant expansion in the number of Irish ECEC degree programmes in the past 10 
years. ECEC students undertake at least two practice placements within an education or childcare setting. There is a practical requirement to know more about students' experiences on placement and how placements aid their learning. Stories told about placement can be one way of enlarging our understanding. Second, there is also a social justification for finding out more about what aids ECEC students to become competent practitioners, as Early Childhood Education and Care (ECEC) policy and practice has evolved rapidly in Ireland since 2010 (Mhic Mhathúna \& Taylor, 2012). For example, the Irish State introduced a free, universal preschool year in ECEC in 2010; Síolta - the quality control framework for ECEC services - has been implemented; and Aistear, the Early Years Curriculum, is up and running. As the number of Irish children participating in pre-school education and care settings has risen, there is a growing social policy need to ensure that pre-school educators are accessing appropriate learning opportunities during their practice placements to raise the quality of the pre-school care and education for young children. As Jones \& McBeth (2010) note, narrative inquiry performs a significant role in public policy literature.

A suitable methodological approach is required to address the substantive aim of any research project. A primary reason for employing narrative inquiry in education research is that stories can organise human experience as people relate experiences through stories (Kim, 2015). Narrative inquiry enables researchers to gather, understand and represent real-life experiences told through stories. Clandinin \& Huber (2010) break down the elements of narrative inquiry into three parts. To think narratively about a phenomenon such as experience involves thinking about three 'commonplaces': temporality, sociality and place. Let me relate these elements to potential stories of ECEC students' experiences of practice placements. As ECEC practice placements take place over time, using narrative inquiry facilitates respondents to reflect back on what 
an event or a series of events may mean for them. But this meaning can be very much informed by subsequent experiences, so when a respondent reflects on their previous experiences, we need to recognise that respondents are constructing and repeatedly revising their autobiographies (Carr, 1986). Second, Clandinin \& Huber (2010) suggest that researchers need to be think about the sociality of experiences. This means that stories emanating from this research needed to be considered in terms of the personal reactions and social interactions of respondents. In terms of education research, Dunne (2003, p.367) suggests, 'to understand a teacher's practice (on her own part or on the part of an observer) is to find an illuminating story (or stories) to tell of what she has been involved in with her students'. Thinking narratively about the sociality of ECEC student experiences enables us to consider how respondents reflect on the emergence of professional selves arising from the personal reactions to and social interactions within practice placements.

Third, ECEC students undertake practice placements in particular settings; Clandinin \& Connelly (2000) remind us that places can shape the meanings of narratives, as places are the locations in which experiences occur. The placement setting is different to the college environment and is not a neutral location. Waters (2017) acknowledges the emergence of a 'spacial turn' in education theory; Von Bromssen (2017) suggests that socio-spacial theories used in education research attempt to understand how the 'where' influences education. For some narrative researchers, identities are linked with experiences within particular places. Cheng (2016), for example, considers the impact which a place might have on the formation of EFL university teachers. Places in narrative inquiry are therefore no longer viewed just as sites where ECEC students learn to perform, but as the catalysts and products of social actions, in which they can be provided with 'a sensory experience that can both orientate and alienate' (Luhman \& 
Cunliffe, 2013, p.135). When it comes to understanding the nature of learning during a practice placement, Clandinin \& Connelly (2000) are reminding us not to ignore the effect of a placement space on students' experiences and on the stories told about these experiences.

\section{Theorising Stories of ECEC Student Placement Experiences}

Narrative inquiry by itself is unable to comprehend the everyday practice placement world of ECEC students. Education theories were used to illuminate the temporal, social and situational experience to which narrative inquiry attends.

The study made particular use of two education theories: 'Threshold Concepts' (Meyer and Land, 2003) and 'Communities of Practice' (Lave \& Wenger, 1991).

\section{Threshold Concepts}

Meyer \& Land's (2003) 'Threshold Concepts' theory became popular among educationalists trying to make sense of critical learning moments for students preparing to become professionals. The theory's key proposition is that 'there are certain concepts, or certain learning experiences, which resemble passing through a portal, from which a new perspective opens up, allowing things formerly not perceived to come into view' (Land et al., 2010, p.ix). Going through the portal enables students to experience new ways of understanding the essential elements of a discipline or profession. Straight away the metaphor points to a learning journey with temporal, social and situational experiences. In scientific subjects such as mathematics and physics it might make sense to identify 'threshold concepts', but in professions such as social work, nursing and ECEC it may make more sense to discern the nature of 
'threshold practices' as learners enhance their learning through engaging in social practices with others over time while in an ECEC placement setting.

Threshold concepts or practices have a number of key features (Land et al., 2010, pp.ixx; Cousin 2006, p.4; Meyer \& Land 2003, p.6), which have been termed transformative, integrative, irreversible, troublesome and bounded. These features can be identified in respondents' stories to scrutinise key learning experiences during ECEC practice placements.

\section{Communities of Practice}

Morgan (2012, p.218) argued that the essential quality defining a threshold concept is its transformative aspect. Crossing the portal can lead to a shift 'in identity and subjectivity, with procedural knowledge, or the ways of thinking and practising customary to a given disciplinary or professional community' (Land et al., 2010, p.xi). For those training to become practitioners, Land et al. (2010, p.xi) further suggest ...there is often an 'underlying game' in which ways of thinking and practising that are often left tacit come to be recognised, grappled with and gradually understood. This underlying game is a common feature of the processes of entry, meaning making and identity formation typically required for entry to a given community of practice.

Land et al. (2010, xi)

Land et al.'s (2010) reference to the term 'community of practice' resonates with Lave and Wenger's (1991) work. Lave and Wenger (1991) introduced the term 'communities of practice' to examine how apprentices and student practitioners learn in informal learning environments such as practice placements. Lave and Wenger (1991) proposed a model of situated learning in which learning is dependent upon students participating in a community of practice. The nature of this participation is partly informed by the culturally specific form that participation takes within an organisation. The position of students early on in practice placements can be best described as one of 'legitimate 
peripheral participation' (Lave and Wenger, 1991, p.108), where students are identifying and learning ways to communicate. For learning to occur, students must adjust to the form that participation takes, often with a tacit dimension present (Eraut, 2000, p.114). Learning develops through a set of relationships being forged over time. The idea of periphery suggests that as students learn to become more competent they move from a location on the fringes of an organisation to a place where 'full participation' (Lave and Wenger, 1991, p.37) may become a possibility. Mastering 'knowledge and skill requires newcomers to move toward full participation in the sociocultural practices of a community' (Lave and Wenger, 1991, p.29). This proposition suggest that narrative inquiry could be a feasible research approach to examine whether practice placements provide a 'community of practice' learning experience for ECEC students. Moving from the periphery to full learning brings to mind a learning journey. Again journeys take time as students change their positioning; journeys occur within a situated or placement setting; journeys require students to engage with others to learn the practices of becoming an ECEC professional. Clandinin \& Huber's (2010) 'commonplaces' approach to understanding these learning experiences through storytelling comes to mind.

\section{Methodological Issues}

ECEC students undergo learning experiences during practice placements, but how can we understand the nature of these experiences, given that we have no direct way of accessing them? If we accept that experiences can be captured through stories, then narrative inquiry can examine temporal, relational and spacial dimensions of ECEC students' learning experiences. Six final-year ECEC undergraduate students and six ECEC agency supervisors were interviewed in North-West Ireland to obtain detailed 
stories of students' learning journeys during 12-week practice placements (see Taylor (2014) for more discussion about the research design).

The narratives of respondents were first analysed using Labov \& Waletzky's (in Esin, 2011, p.104)) structural model. The structural model (see Esin, 2011, p.104) identifies how the building blocks of stories come together. The approach treats stories of respondents as texts that function as constructions of past events and experiences. The focus of analysis in the structural model is on the way an experience usually in the form of an event is told in a story text. ECEC practice placements can be viewed as one overall event or a series of events, involving activities and practices. The attraction of Labov \& Waletzky's model is that it offers a series of questions comprising descriptive and evaluative elements that can be asked to examine the structure of a story of a respondent's experiences. Of interest was how respondents represent a sequence of events, related to key learning experiences and professional identity formation. Labov \& Waletzky's model aids an understanding of how respondents framed key learning experiences, by proposing that such experiences are likely to involve a series of executed, connected and reflected upon events. By telling their stories respondents are taking decisions to construct versions of what they deemed to be important learning experiences for ECEC students on placement. Listening to digital recordings of interviews and reading interview transcripts, I identified structural features of stories and the representation of past events.

Stories were also analysed looking for themes related to significant learning experiences. In using thematic analysis in narrative inquiry, Riessman (2005, p.2) suggests emphasis is placed 'on the content of a text, "what" is said more than "how" it is said, the "told" rather than the "telling". Thematic analysis taking place within a narrative approach can consider the intersections of time, sociality and place in people's 
accounts of their experiences. These 'commonplaces' can be identified within Land et al.'s (2010, p.ix) metaphor describing the nature of the learning journey students undergo. Specifically, their image of travelling through a portal to represent key learning breakthroughs offers a sense of the learning journey ECEC students need to undertake while on practice placements. Journeys imply movement across time, perhaps conducted through a series of activities requiring interactions with others; journeys also imply a landscape to traverse. To unlock this metaphor, Meyer \& Land (2003) suggest examining for features of the threshold concepts framework to investigate the meaning of key learning experiences. Therefore, in my study, troublesome, integrative and transformative elements of learning were probed for within ECEC practice placement stories.

Stories were further analysed for the changing social positions of ECEC students over the course of their placements. The idea of sociality (Clandinin et al., 2015) encapsulates a number of elements, one of which can be witnessed in terms of changes to social positioning. Bamberg (1997, p.337) provides a useful summary of how these changes can be analysed in stories. First, researchers can examine how the storyteller locates themselves in relation to other characters in a story. Second, researchers can consider how the storyteller positions himself to the direct and indirect audience recipients. Third, how the storyteller positions themselves in relation to themselves. Of interest in this study is how characters in a story position themselves in relation to others or to different or early versions of themselves. In terms of ECEC practice placements, changing positions may be analysed in terms of what students do or say over the course of their placement. The communities of practice literature suggests that the position students adopt early on in practice placements can be best described as one of 'legitimate peripheral participation' (Lave and Wenger, 1991, p.108), a time when 
students are identifying and learning ways to communicate. For learning to occur, students must adjust to the form that participation takes. One way to participate is to learn how to talk like ECEC practitioners. Lave and Wenger (1991, pp.108-9) note, 'the purpose is not to learn from talk as a substitute for legitimate peripheral participation; it is to learn to talk as a key to legitimate peripheral participation'. However, as Connelly and Clandinin (1988) remind us, the specific placement environment remains significant in shaping how opportunities emerge to learn to talk.

\section{Findings}

This section explores three findings from the stories told by respondents. These findings have been chosen to reveal the richness of narrative inquiry, pointing to the presence of temporality, sociality and place in respondents' accounts of how they tell stories about key learning experiences for students during ECEC practice placements.

\section{Surviving the Early Period of ECEC Practice Placements}

Despite studying ECEC-related subjects at college, many students enter the ECEC practice world as neophytes. The early days of placement can see students functioning in a 'liminal state', operating between two identities (Meyer \& Land, 2005, p.374). They no longer embody the pre-placement student identity, but as they have not executed a threshold practice, a practitioner identity remains out of reach. Land et al. (2010, p.x) suggest the struggle to understand the nature of a threshold concept can leave learners in a 'stuck place',

Marlene $^{1}$, a community preschool supervisor, elegantly described the early stages of placement which students need to endure to advance their understanding of what it

\footnotetext{
${ }^{1}$ All names have been anonymised.
} 
means to operate as an ECEC practitioner. The student is frequently bewildered during the first part of placement. She depicted how students can be initially lost when they arrive in a placement setting, 'it's all new territory.' Part of a student's initial learning journey during a practice placement involved identifying how the childcare organisation functions, particularly so for students who have had little or no prior work experience of preschool settings:

...okay what are the rules here, what am I dealing with? what's going on here?' and that's a lot, and certainly for somebody who has no professional work experience...they have nothing to compare it with, there is no language...they have no language they can talk...

(Marlene, supervisor)

Not surprisingly, for those students who have had little or no previous childcare work experience, the first few weeks of a practice placement can be difficult. Judy, a student respondent, reflecting back on her first practice placement noted:

The few couple of week were overwhelming, didn't know what to do or anything because it was the first time that I was in a crèche and I hadn't a clue about whether I liked it or not...

(Judy, final-year ECEC student)

In the early stages of placement, ECEC students share a particular property with wobblers in their care: both are trying to find their feet. They have left college and entered an unfamiliar culture. They have to get to know ways of seeing and doing things in their placement agency (e.g. how children are welcomed to the setting; daily and weekly programmes; how rules and regulations impact on day-to-day work; etc.). Acquiring this knowledge does not come quickly or overnight, so the early phase of placement can be particularly troubling for students, inducing difficult emotions and tiredness, as final-year ECEC student Una reflected:

When I first went out on placement I used to find it so hard, I used to dread going in in the mornings, I used to hate it when they asked me to do things, I 
would be afraid that I would get it wrong or something, if I tried to take on or organise an activity myself...the first couple of weeks, I used to come home from work and fall on the couch, it was so tiring, and you stand on your feet all day and you don't get to sit down much.

(Una, final-year ECEC student)

The ECEC agency milieu can hamper students' progress. For example, Heidi, a supervisor, highlighted the busyness and noisiness of the placement environment, conditions unfamiliar to many ECEC students, conditions with which they have to come to terms:

Well you have to see that a preschool setting is a very dynamic environment...it's very busy and...I mean busy as in many people think their workplace is busy but preschool you walk into the door and you're full-on until you leave again, so that's 8-hour full-on hard work...

(Heidi, supervisor)

At the same time there was a recognition that ECEC students differ in the level of their personal resilience, influencing how quickly they learn to settle in the practice placement environment. For example, Heidi indicated that students respond to placement knockbacks in different ways:

...some other students might pick up on something that didn't work out and not exactly go the opposite way, but might take longer to re-fuel...so it depends very much on how they face challenges and how they work or figure out for themselves how something doesn't work out, how do I deal with this...that's sort of a way

(Heidi, supervisor)

The first supervisor-student supervision sessions can provide a space for students to articulate their concerns (e.g. how to undertake tasks and activities) and receive reassurance, as Heidi observed:

...in the first supervision they [the student] might say 'I need to be more confident...my confidence is kind of...or I don't know how to handle this'...they wouldn't say 'afraid' but they know that behaviour issues might kind of challenge them a bit and that's closely linked to confidence. 
(Heidi, supervisor)

Maria, a supervisor, described the difference between how students perform early and later on placement, '... when they start they're just watching everything and towards the end they just partake and they're just like paid staff really...'

The early stages of practice placements can be difficult for ECEC students as they try to understand how agencies and personnel function. Before executing threshold practices successfully, students need to understand organisational culture and practices.

\section{Finding One's Voice to Practice}

The early part of a practice placement can be a tiring and stressful time, as students observe and start to perform agency functions, often under the watchful eyes of a supervisor. The development of professional identity sees individuals becoming comfortable with a place, a comfort built on a sense of their capacity to share their knowledge and skills, a capacity to work well with others (Heikkinen, in Tamm, 2010, p.69). This remains out of reach for students in the early phase of placement. Instead what may be happening is that students are both struggling and learning to participate in a community of practice.

More specifically, respondents such as supervisor Maria noted that ECEC students can be 'really shy and have to be told to do something.' In student Liz's story she found it difficult to ask her supervisor's permission to initiate an activity.

Yeah, it was nerve-racking to know where your limits, how you can say 'can I do this?' or you know it's getting the confidence to say can I take this activity today, or can I - and then you're always thinking in the back of your mind you need to be supervised in everything you do and you need to make sure that you're not stepping the mark saying 'can I do this, but you need to stand and watch me', and you're not getting annoy-, well they need to be in the room with you obviously. 
What these respondents were referring to was a position students struggled to inhabit during the early stages of practice placements, namely one of legitimate peripheral participation (Lave \& Wenger, 1991, p108). The key to legitimate peripheral participation is 'to learn to talk' (Lave \& Wenger, 1991, p108). But learning to talk provides students with a challenge: they have to adjust to the cultural form of participation the practice agency espouses. Supervisor Marlene illustrated vividly this point. She described how the early part of the journey involved students learning to understand the placement agency's rules and language, as 'they have no language they can talk.' By acquiring this language, students are trying to procure a set of 'cultural glasses' more experienced ECEC practitioners wear. The lens in these glasses provide students with a means to perceive the world as ECEC practitioners do, to make decisions as ECEC practitioner do and eventually to practice as ECEC practitioners do. As Irvine \& Carmichael's $(2009,104)$ propose, threshold practices can be viewed 'as key elements of a community's shared repertoire'.

Maria, a supervisor in a community preschool setting, suggested students became more communicative as they became more confident executing tasks. To illustrate the nature of this transformation, Maria offered an example of how ECEC students showed greater articulation over time concerning the agency task of transporting preschool children. Initially, at the beginning of placement, ECEC students can be 'really shy and have to be told to do something.' After a few weeks, students 'might think it but they wouldn't come out and say well maybe we should head off now... at the beginning, a lot of them wait to be told.' Later on, students start to say, “oh, it's half-two, will I go on [e.g. preschool bus], whatever?” As Lave \&Wenger (1991, pp.108-9) note, 'the purpose is 
not to learn from talk as a substitute for legitimate peripheral participation; it is to learn to talk as a key to legitimate peripheral participation'.

ECEC students also discussed the challenging process of literally finding one's voice to direct placement activities. Liz provided an example of how difficult it can be for students to ask supervisors' permission to lead an activity:

Yeah, it was nerve-racking to know where your limits, how you can say 'can I do this?' or you know it's getting the confidence to say can I take this activity today, or can I - and then you're always thinking in the back of your mind you need to be supervised in everything you do and you need to make sure that you're not stepping the mark saying 'can I do this, but you need to stand and watch me', and you're not getting annoy-, well they need to be in the room with you obviously.

$$
\text { (Liz, final-year ECEC student) }
$$

Marlene, a supervisor, noted the transitional phase could be tiring for students. But getting through this phase can be rewarding, with confidence becoming embodied, 'from that very tired face they become a bit more bubbly and a bit more relaxed and the coolness starts up and that's great.'

\section{Directing Encounters with Children}

The early days of a practice placement frequently challenge the ECEC student, so it must be difficult for her to envisage successfully executing, later on in placement, a 'threshold practice'. In these early days, the ECEC student can struggle to find her feet and voice; she watches the organisation at work and observes day-to-day routines; she soaks up the workplace culture. In the first few weeks of placement, supervisors frequently tell ECEC students what to do - protecting students from themselves and children in their care. Meanwhile students have to gauge and respond to supervisors' expectations. But at some stage the ECEC student steps from the shadows and moves to 
a position where she plans, executes and reviews an activity or interaction with young children. For the essence of becoming a professional is to learn how to competently direct encounters with service users (Eraut, 2008, p.6).

The threshold practice in ECEC relates to successfully planning, implementing and reviewing an activity or interaction with young children in a preschool setting. Una, a student respondent, possibly best summed up the practice:

On placement you are given the opportunity to use your own initiative and to do things on your own, then you realise how to work as a childcare practitioner. You kind of have to go about it yourself, like other people can kind of tell you how to do things, but you need the practice placements to be able to help you grow.

(Una, final-year ECEC student)

Narrative inquiry provides somebody like Una with an opportunity to talk about the 'contradiction and discontinuity' (Clandinin \& Connelly, 1986, p.386) in learning to become a practitioner. Her account also reveals her changing subject positioning in relation to herself and to others over the course of her placement. Her narrative revealed the presence of troublesome, integrative and transformative features associated with the successful execution of a threshold practice. For instance, as noted earlier, Una struggled at the start of her placement: she was afraid of undertaking activities and getting them wrong. However, after spending a number of weeks in the placement agency and becoming familiar with activities and routines, Una recollected that one day her manager said: 'You come in tomorrow with your own activity, you do it yourself with the children.' The next day she was nervous going into work, she told me. But after successfully implementing the activity, she was delighted. When asked about the activity's make-up, Una responded:

I read a story with the kids - I kind of made it up myself. We did table top activities and different things and I supervised them. She [supervisor] just sat over in the corner and let me do it, it was nerve-wracking...She was doing her own kind of thing, I knew well she was kind of looking over and back to see... 
(Una, final-year ECEC student)

Una judged how well the activity went by assessing the children's response:

...the children kept their concentration a good while, and then they were able to reflect on what they were doing; it showed they were kind of paying attention to what I was asking them to do and they sat there for a good 10 or 15 minutes, so I thought that was kind of an achievement.

(Una, final-year ECEC student)

Here Una is critically reflecting on her effort to locate a successful rhythm within her teaching. She is telling a story in which she evaluates her efforts. By telling a story she has created an opportunity to reconstruct a narrative of experience and critically reflect on the process of becoming an ECEC practitioner. As Clandinin and Connelly (1986) indicate, narratives provide novice teachers with opportunities to reflect on their practice experiences to develop their teacher knowledge.

The successful execution of this activity laid the foundations for Una to take on a more creative and resourceful placement role, by directing other activities with the children:

And then I was doing activities and things on my own all the time. And in the 10th and 11th week I was doing so many things on my own. I definitely think you need to do that - it was very scary.

\section{(Una, final-year ECEC student)}

Una stated her confidence grew as a result of successfully completing these activities, a transformation recognised by her visiting college tutor: 'the supervisor from the college said that I was a totally different person in 12 or 13 weeks'. Una's story reveals how she makes sense of a change in her social positioning, in relation to an earlier version of herself and in terms of her relationships with others (Bamberg, 1997).

Heidi, a supervisor, concurred with Una on the need for students to demonstrate initiative with younger children, noting such actions require some confidence: 
.... really good student would be someone who likes to try out things and that again goes with the confidence... who comes with ideas, because we're always happy to get new ideas in, we're always happy to see students who bring in new ideas...erm a good student would work well after a certain period of induction on their own initiative a lot because that's exactly what's required later on in the job because there's nobody in the room to tell you all the time what to do so to develop a sense of what's needed, what needs to be done at a certain time.

(Heidi, ECEC supervisor)

The successful management of encounters, such as an activity with younger children, may therefore constitute a threshold practice for ECEC students during a practice placement. Instead of supervisors orchestrating their endeavours, ECEC students learn to direct their own work by, for instance, organising an activity for younger children. Gaining confidence on placement from successfully completing a threshold practice can lead to students initiating further activities and becoming more open to accepting critical feedback, as Maria remarked:

... they just take it upon themselves to organise activities or go and sort out dinners or whatever, not afraid to go and do it and be well you know told off 'why did you decide?'... they just use their own initiative.

(Maria, supervisor)

\section{Discussion}

Clandinin and Connelly (1986, p.385) suggest a narrative approach to schooling offers 'the potential for freeing education from a language of the technical, for ensuring that understandings link with fundamental qualities of human experience'. Stories can therefore foreground the human and reflective dimensions of learning journeys that ECEC students undergo during their practice placements. Stories, for example, reveal that learning becomes embodied as ECEC students learn to exercise their voices over the course of a placement, in the process becoming more relaxed and confident. This contrasts with the earlier period of placement, when feelings of fear and anxiety about what to do can predominate. Students, however, experience a sense of relief, euphoria 
and joy as a result of successfully navigating a threshold practice. It is as if a number of elements have come together (e.g. years of study; understanding ECEC workplace culture; ability to undertake an activity with younger children). Students draw on this repertoire of knowledge (Schön, 1983) to inform what they do.

Students also reset their ontological understanding (Land et al. 2010, pp. ix-x) of what it means to perform as an ECEC practitioner. The ontological shift relates to their journey to become a self-directed and reflective practitioner, with less emphasis placed on ‘technical-rational' ways of knowing (Schön, 1983). While textbooks are helpful, they do not offer sufficient knowledge to survive on placement. Part of changing students' ontological perspective involved what Stibbe (2010) calls critical identity work; students update and change their understanding of what it means to operate as a practitioner, taking into account their immediate context and the actual world around them. The ECEC preschool placement world is a place where students critically reflect to make sense of various phenomena including interactions with others. The placement setting and the people located in this space influence how the ECEC students learn to practice. This sense of critical reflection is witnessed in stories reflecting on the learning journey, a progression through a series of stages: disorientation, observing and mimicking practice, before devising activities or responding to encounters with younger children. Narrative inquiry enables respondents to examine how students negotiate these events over time with people within a particular setting.

Successful students become less hesitant about performing a practitioner role as they learn to participate 'legitimately’ (Lave \& Wenger, 1991, p108) in ECEC work. So while the ECEC student might remain a novice practitioner - on the periphery - she can take inspiration from her placement achievements, as she moves towards the early stages of her career. As Hall (2002, p.192) suggests, achieving goals, such as executing 
threshold practices, leads to an inner sense of success, raising self-confidence and providing evidence to support a view that one's professional identity is forming.

Different factors help students to integrate new knowledge. If the placement agency corresponds to a community of practice, it can offer a space where situated learning opportunities may arise (Lave \& Wenger, 1991). ECEC agencies represent shared domains of interest, where the goal is to care and educate a group of younger children. Opportunities emerged for students to discuss, reflect and plan activities and encounters with young children. Supervisors play their role by offering new ways to think and practice (Land et al. 2010, p.xi).

\section{Conclusion}

Narrative inquiry is a powerful methodological approach as it can reveal the nature of key learning experiences for ECEC undergraduate students on practice placements. Education theories enable researchers to make sense of these key learning experiences. However, it would be disingenuous to say that this paper reveals the full story. The provisional nature of findings in social science research becomes apparent when one reviews research data after some time. Just as different stories would likely emerge if respondents were interviewed again today - accounts shaped by their subsequent life experiences - the interpretation of these stories are also likely to be different as new theoretical insights emerge to explain professional formation. What this suggests is that while narrative inquiry remains an important methodological approach to convey powerful messages associated with lived experiences, only provisional knowledge claims can be made. On one hand, this may be seen to undermine emancipatory claims associated with narrative inquiry in that knowledge claims are difficult to generalise to larger population groups. On the other hand, Clandinin et al. (2015) view narrative inquiry as a way to produce knowledge which is different to paradigmatic knowledge. 
As such it offers a more human and reflective approach to understanding people's experiences. Narrative inquiry also plays an emancipatory role as narratives allow for the possibilities of biographical revisions, new voices to be heard and new insights to emerge about prevailing educational discourses. As Clandinin \& Connelly (1998, p.247) propose, narrative inquiry offers the potential to reshape life in educational establishments, as stories about lives witness the 'possibilities for growth and change'.

\section{Bibliography}

Agnew, J. 2011. "Space and place." In The SAGE handbook of geographical knowledge, edited by J. Agnew and D.N. Livingstone, 316-330. London: London. Bamberg, M. 1997. "Positioning between structure and performance." Journal of narrative and life history 7 (1-4):335-342.

Carr, D. 1986. Time, narrative and history. Bloomington: Indiana University Press. Chase, S. E. 2005. "Narrative inquiry: Multiple lenses, approaches, voices." In The Sage Handbook of Qualitative Research, edited by N. Denzin and Y. Lincoln, 651-679. London: Sage.

Cheng, X. 2016. "A narrative inquiry of identity formation of EFL university teachers." Journal of Education and Training Studies 4 (5):1-7.

Clandinin, D. J, and J. Huber. 2010. "Narrative inquiry." In International encyclopedia of education, edited by B. McGaw, E. Baker and P.P. Peterson, 436-441. New York, NY: Elsevier.

Clandinin, D.J., and F.M. Connelly. 1986. "Rhythms in teaching: The narrative study of teachers' personal practical knowledge in classrooms." Teaching and Teacher Education 2:377-387.

Clandinin, D.J., and F.M. Connelly. 2000. Narrative inquiry. San Francisco, CA: Jossey-Bass.

Clandinin, J., V. Caine, A. Estefan, J. Huber, M.S. Murphy, and P. Steeves. 2015. Places of Practice: Learning to Think Narratively. Narrative Works 5 (1). Accessed Nov 30 2017. https://journals.lib.unb.ca/index.php/NW/issue/view/1799 
Connelly, F. M., and D. J. Clandinin 1990. "Stories of experience and narrative inquiry." Educational Researcher 19 (5):2-14.

Connelly, F.M., and D.J. Clandinin. 1988. Teachers as curriculum planners: Narratives of experience. New York, NY: Teachers College Press.

Connelly, F.M., and D.J. Clandinin. 1990. Stories of experience and narrative inquiry. Educational Researcher 19 (5):2-14.

Connelly, F.M., and D.J. Clandinin. 2006. "Narrative inquiry." In Handbook of complementary methods in education research, edited by J. Green, G. Camili and P. Elmore, 477-487. Mahwah, NJ: Lawrence Erlbaum.

Cook, V.A., and P. J. Henning. 2011. "Education spaces: embodied dimensions and dynamics." Social \& Cultural Geography 12 (1-8).

Cousin, G. 2006. "An introduction to threshold concepts." Planet, 4-5.

Delpit, L.D. 1995. Other people's children: Cultural conflict in the classroom. New York, NY: New Press.

Dunne, J. 2003. "Arguing for Teaching as a Practice: a Reply to Alasdair MacIntyre." Journal of Philosophy of Education 37 (2):353-369.

Eraut, M. 2000. "Non-formal learning and tacit knowledge in professional work." British Journal of Educational Psychology 70 (1):113-136.

Eraut, Michael. 2008. How professionals learn through work. Accessed June 32016. http://surreyprofessionaltraining.pbworks.com/f/How+Professionals+Learn+through+W ork.pdf

Esin, C. 2011. "Narrative Analysis Approaches." In Qualitative Research Methods in Psychology: Combining Core Approaches, edited by Nollaig Frost. Maidenhead: Open University Press.

Hall, D. T. 2002. Careers in and out of organizations. Vol. 107. London: Sage. Huber, J., V. Caine, M. Huber, and P. Steeves. 2013. "Narrative Inquiry as Pedagogy in Education: The Extraordinary Potential of Living, Telling, Retelling, and Reliving Stories of Experience." Review of Research in Education 37 (1):212-242.

Irvine, N., and P. Carmichael. 2009. "Threshold concepts: A point of focus for practitioner research." Active Learning in Higher Education 10 (2):103-119. Jones, M.D., and M.K. McBeth. 2010. "A Narrative Policy Framework: Clear Enough to Be Wrong?" The Policy Studies Journal 38 (2):329-353.

Kim, J-H. 2015. Understanding Narrative Inquiry. London: Sage. 
Land, R., J.H.F Meyer, and C. Baillie. 2010. "Editors' Preface: Threshold Concepts and Transformational Learning." In Threshold Concepts and Transformational Learning, edited by J.H.F Meyer, R. Land and C. Baillie. Rotterdam: Sense Publishers.

Lave, J., and E. Wenger. 1991. Situated Learning. Legitimate Peripheral Participation. Cambridge: Cambridge University Press.

Luhman, J. T., and A. L. Cunliffe. 2013. Key concepts in organization theory. London: Sage.

Meyer, J., and R. Land. 2003. "Threshold Concepts and Troublesome Knowledge (1) Linkages to Ways of Thinking and Practising'." In Improving Student Learning - Ten Years On, edited by C. Rust. Oxford: OCSLD.

Meyer, J., and R. Land. 2005. "Threshold concepts and troublesome knowledge (2): Epistemological considerations and a conceptual framework for teaching and learning." Higher Education 49 (3):373-388.

Mhic Mhathúna, M., and M. Taylor, eds. 2012. Early Childhood Education and Care. An Introduction for Students in Ireland. Dublin: Gill and Macmillan. Morgan, H. 2012. "The Social Model of Disability as a Threshold Concept: Troublesome Knowledge and Liminal Spaces in Social Work Education." Social Work Education 31 (2):215-226.

Polakow, V. 1994. Lives on the edge: Single mothers and their children in the other America. Chicago, Il: University of Chicago Press.

Riessman, C.K. 2005. "Narrative Analysis." In Narrative, Memory \& Everyday Life, edited by N. Kelly, C. Horrocks, K. Milnes, B. Roberts and D. Robinson, 1-7. Huddersfield: University of Huddersfield.

Schön, D. (1983) The Reflective Practitioner. How professionals think in action, London: Temple Smith.

Stibbe, A. 2010. "Identity Reflection: students and societies in transition." Learning and Teaching in Higher Education (5):86-95.

Tamm, T. 2010. Professional Identity and Self-concept of Estonian Social Workers. Department of Education, University of Tampere. Accessed June 32016. http://tampub.uta.fi/bitstream/handle/10024/66631/978-951-44-8115-4.pdf?sequence=1 Taylor, M. 2014. "What Early Childcare Students Find 'Troublesome' During Practice Placements." AISHE-J: The All Ireland Journal of Teaching \& Learning in Higher Education 6 (2). 
Von Bromssen, K. 2017. "Socio-spatial theories - a short introduction." In Location, Space and Place in Religious Education, edited by M. Rothgangel, K. Von Bromssen, H-G. Heimbrock and G. Skeie. Munster, Germany: Waxmann Verlag GmbH. Wallace, M., and A. Wray. 2011. Critical Reading and Writing for Postgraduates. 2 ed. London: Sage.

Wang, C., and S.K. Geale. 2015. "The power of story: Narrative inquiry as a methodology in nursing research." International Journal of Nursing Sciences 2 (2):195198.

Warf, B., and S. Arias. 2009. "Introduction: The reinsertion of space in the humanities and social sciences." In The spatial turn: Interdisciplinary perspectives, edited by B. Warf and S. Arias, 1-10. London: Routledge.

Waters, J. L., 2017. "Education unbound? Enlivening debates with a mobilities perspective on learning." Progress in Human Geography 41 (3):279-298.

Willig, C., 2012. Qualitative Interpretation and Analysis in Psychology. Maidenhead: Open University Press. 
